\title{
RUSSIA'S BANKING SECTOR IN SEPTEMBER 2015
}

\author{
M.Khromov
}

In September 2015, banks produced the best financial result this year due to slow down of reserves growth. Credit portfolio grows in the corporate segment and the main flow of financial resources remains as repayment of funds previously borrowed from the Bank of Russia.

September increase of banking sector assets constituted $1.5 \%^{1}$ and in Q3 banking sector assets went up by $2.5 \%$. However, for the period from the turn of 2015 assets movement remains negative - over nine months their contraction came to $2.8 \%$. Nevertheless, annual increment of assets (against corresponding date of the previous year) most likely passed its minimum in summer 2015. By 1 October 2015, annual growth of assets increased to $7.2 \%$ against $4.3 \%$ as of 1 August 2015 .

Main source of banking sector liabilities both in September and in Q3 2015on the whole were corporate customers' assets. Individual customers' assets continued growing. However, their share in the total resource base of the banks was noticeably lower. In addition, significant share in the banking sector liabilities in Q3 2015 constitutes the Finance Ministry's assets on deposits. Financial resources were mainly directed at repayment of debt before the bank of Russia and granting loans to corporate customers.

1 Hereinafter, if not otherwise specified, the growth rates of balance-sheet indices are adjusted by changes in the value of their components denominated in foreign currencies, but without the adjustment by the data for banks whose licenses have been revoked. To eliminate the effects of the ruble exchange rate movement, all the components of the banking sector's balance sheet denominated in foreign currencies are recalculated in terms of US dollar's exchange rate as of a given date, all changes are recalculated in terms of USD, and the ruble-denominated component's changes are estimated by applying the monthly average ruble to USD exchange rate.

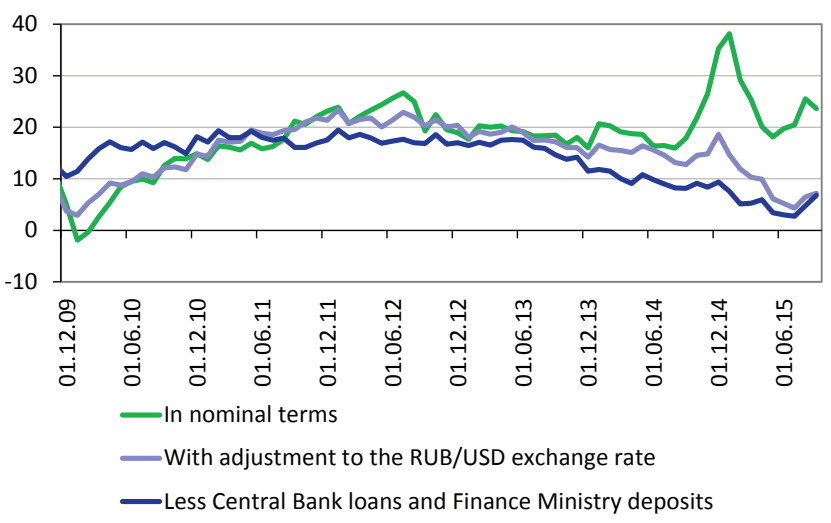

Sources: CBR, IEP calculations.

Fig. 1. The dynamics of the banking sector assets as compared to the corresponding date of the previous year (growth, \%)

According to IET preliminary estimated, in September bank stock shrank by $0.2 \%$. Meanwhile, total capital of major state banks ${ }^{2}$ has remained on hold over the month and all reduction was accounted for by other banks. Capital adequacy on the whole both in the banking sector and major state banks as of 1 October 2015 came to $12.9 \%$. This signifies that for a period from the turn of the year major state banks have improved total capital ratio by over than 1 p.p. Meanwhile, total capital ratio for other banks fell by 0.5 p.p. (Table 1).

2 Sberbank, banks of VTB group (VTB, VTB24 and Bank of Moscow), GPB, Rosselkhozbank.

Table 1

BANK STOCK AND SUFFICIENCY CAPITAL RATIO IN 2015

\begin{tabular}{|c|c|c|c|c|c|c|}
\hline & 1.12 .2014 & 1.01 .2015 & 1.07 .2015 & 1.08 .2015 & 1.09 .2015 & 1.10 .2015 \\
\hline \multicolumn{7}{|c|}{ Capital sufficiency (ratio H1), \% } \\
\hline Banking system & 11.9 & 12.5 & 12.9 & 13.0 & 13.0 & $12.9 *$ \\
\hline Major state banks & 11.1 & 11.8 & 12.3 & 12.8 & 13.0 & 12.9 \\
\hline Other banks & 13.1 & 13.4 & 13.6 & 13.2 & 13.1 & $12.91 *$ \\
\hline \multicolumn{7}{|c|}{ Amount of bank stock, $\mathrm{Rb}$ bn } \\
\hline Banking system & $7,862.2$ & $7,928.4$ & $8,166.4$ & $8,454.3$ & $8,725.8$ & $8,706.2^{*}$ \\
\hline Major state banks & $4,214.7$ & $4,285.7$ & $4,465.0$ & $4,785.0$ & $4,965.9$ & $4,963.9$ \\
\hline Other banks & $3,647.5$ & $3,642.7$ & $3,701.4$ & $3,669.3$ & $3,759.9$ & $3,742.3^{*}$ \\
\hline
\end{tabular}

* IEP estimate.

Sources: $\mathrm{CBR}$, banks books, IEP calculations. 


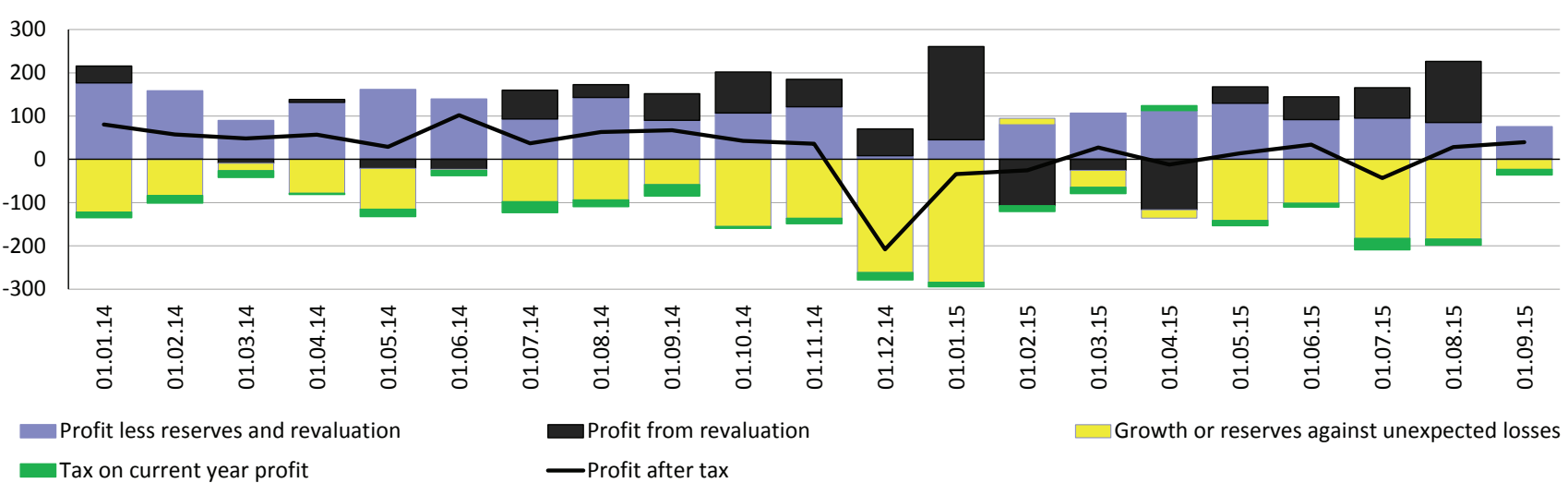

Sources: CBR, IEP calculations.

Fig. 2. The main components of the banking sector's monthly profits, $R b$ bn

September was the best month of the year from the financial results point of view. In September, the Banking sector profit before tax amounted to $\mathrm{Rb}$ $52.0 \mathrm{bn}$ and after tax $-\mathrm{Rb} 40.0 \mathrm{bn}$. Both indicators were highest this year. Overall, for nine months of 2015, banking sector pretax profit amounted to $\mathrm{Rb} 128 \mathrm{bn}$ which is one fifth of the amount of the corresponding period of the previous year ( $\mathrm{Rb} 685.0 \mathrm{bn}$ ). Together with tax, banking sector profit for the first three quarter of 2015 turned out to be 19-fold less than a year before: $\mathrm{Rb} 28 \mathrm{bn}$ against $\mathrm{Rb} 541$ bn.

September growth of the financial outcome, meanwhile, is unlikely to have a sustainable effect. Main contribution to the banks profit growth was due to reduction of transfers to reserves. Over the month, their volume has increased by $\mathrm{Rb} 23 \mathrm{bn}$ meanwhile in the previous months of 2015 average growth of reserves constituted more than $\mathrm{Rb} 100 \mathrm{bn}$. Reduction of transfers to the reserves can be linked with September ruble appreciation ${ }^{1}$ which reduced ruble estimate of the risk assets in denominated in foreign currency and optimization of banks books over the last month of the quarter in order to improve formal profit indicators for the reporting period.

Low net operating income (profit less revaluation and operations with reserves) remain exceptionally negative for the banking sector profitability. In September, the value of this indicator fell to $\mathrm{Rb} 76.0 \mathrm{bn}$ against $\mathrm{Rb} 91.0 \mathrm{bn}$ on average for the previous eight months of 2015 and Rb 118.0bn on average for a month in 2014.

\section{Borrowed Funds}

In September 2015, the volume of retail assets on bank accounts and deposits up $0.9 \%$, over Q3 up $2.4 \%$ and on the whole for the period from the turn of the year up $9.8 \%$.

1 Up 1.5\% both to USD and euro.

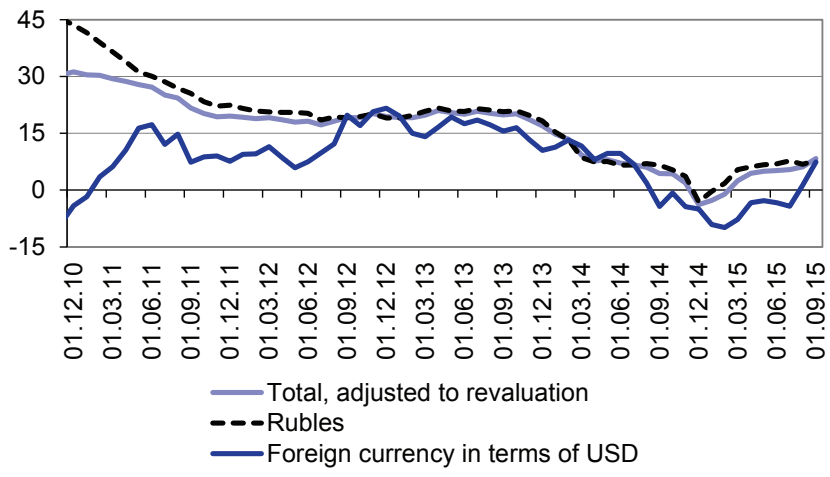

Sources: CBR, IEP calculations.

Fig. 3. The Dynamics of retail deposits as compared to the corresponding date of the previous year (increment, \%)

In 2015, personal saving rate on bank deposits returned to its "normal" level following sharp decline in 2014. For instance, over nine months of 2015, households savings on bank deposits amounted to $\mathrm{Rb}$ 1.77 trillion or $4.7 \%$ of their money income which is not only in absolute terms but in the share of income exceeds 2013 indicator ( $R b 1.41$ trillion and $4.5 \%$ of income).

From the point of view of foreign currency composition, deposits denominated in foreign currency have been growing at a faster rate for the second month in a row. In September, ruble deposits went up by $0.6 \%$ and accounts and deposits denominated in foreign currency increased by $1.8 \%$ in dollar terms. In September, the share of deposits denominated in foreign currency stayed on hold remaining at the level of $29 \%$.

In September, the volume of corporate customers' assets in Russian banks went up by $4.2 \%$, thus setting another record in the current year, for Q3 they went up by $6.7 \%$, and for the period from the turn of the year increased by $5.3 \%$. Annual increment of the corporate customers' assets in the banks as of the period-end for September has exceeded $20.0 \%$ which is a record high from summer 2012. 


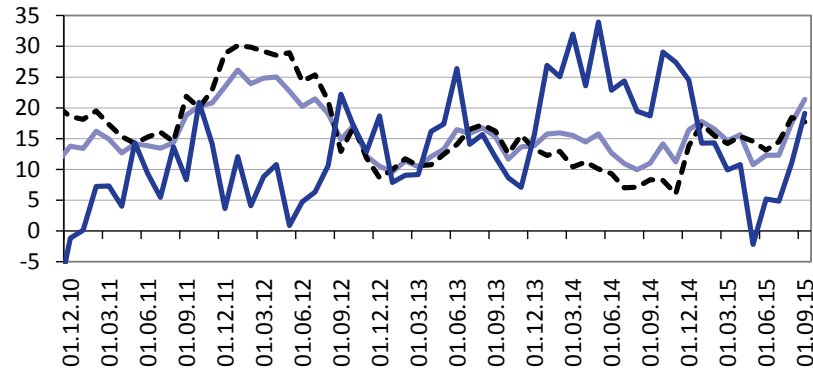

—Total, adjusted to revaluation _ _- Rubles

- Foreign currency in terms of USD

Sources: CBR, IEP calculations.

Fig. 4. The dynamics of corporate customers' accounts to the corresponding date of the previous year (increment, \%)

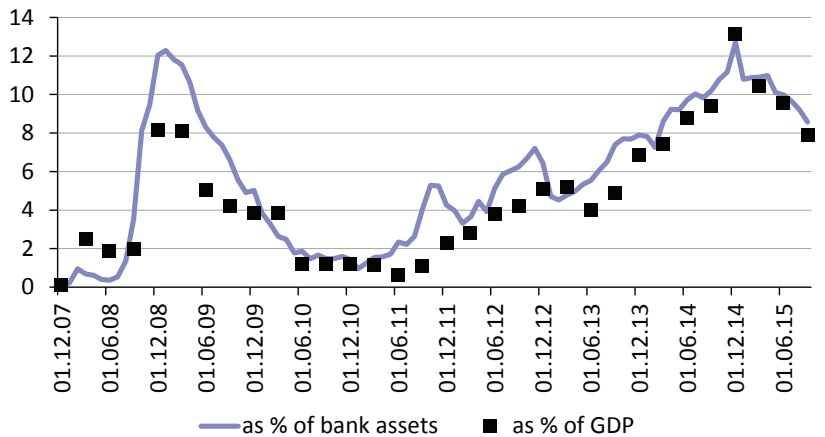

Sources: CBR, IEP calculations.

Fig. 5. The Dynamics of banks' total debt to the Bank of Russia and the Ministry of Finance of Russia (as \% of bank assets and GDP)

Table 2

COMPOSITION OF RUSSIA'S CREDIT ORGANIZATIONS' LIABILITIES (AS OF MONTH END), AS \% OF TOTAL

\begin{tabular}{|c|c|c|c|c|c|c|c|c|c|c|c|c|}
\hline & 12.09 & 12.10 & 12.11 & 12.12 & 12.13 & 06.14 & 12.14 & 03.15 & 06.15 & 07.15 & 08.15 & 09.15 \\
\hline Liabilities, Rb bn & 29430 & 33805 & 41628 & 49510 & 57423 & 61385 & 77663 & 74447 & 73513 & 74841 & 78413 & 79211 \\
\hline Bank stock & 19.3 & 18.7 & 16.9 & 16.2 & 16.0 & 15.8 & 13.6 & 14.8 & 15.5 & 15.7 & 15.4 & 15.3 \\
\hline $\begin{array}{l}\text { Credits allotted by } \\
\text { Bank of Russia }\end{array}$ & 4.8 & 1.0 & 2.9 & 5.4 & 7.7 & 8.7 & 12.0 & 10.2 & 9.4 & 8.9 & 8.3 & 7.3 \\
\hline Interbank operations & 4.8 & 5.5 & 5.7 & 5.6 & 5.1 & 5.9 & 6.1 & 4.5 & 5.0 & 5.0 & 5.1 & 5.9 \\
\hline Foreign liabilities & 12.1 & 11.8 & 11.1 & 10.8 & 9.9 & 9.4 & 10.2 & 9.5 & 8.8 & 8.9 & 9.4 & 9.0 \\
\hline Assets of individuals & 25.9 & 29.6 & 29.1 & 28.9 & 29.4 & 27.4 & 23.7 & 25.4 & 26.8 & 27.0 & 26.7 & 26.6 \\
\hline Corporate sector assets & 25.9 & 25.7 & 26.0 & 24 & 23.8 & 22.9 & 23.8 & 25.0 & 24.6 & 24.4 & 25.0 & 25.7 \\
\hline $\begin{array}{l}\text { Accounts and deposits of } \\
\text { state government bodies } \\
\text { and local administrations }\end{array}$ & 1.0 & 1.5 & 2.3 & 1.6 & 0.9 & 2.3 & 1.4 & 1.8 & 2.0 & 2.2 & 2.3 & 2.7 \\
\hline Securities issued & 4.1 & 4.0 & 3.7 & 4.9 & 4.5 & 3.9 & 3.5 & 3.5 & 3.5 & 3.4 & 3.2 & 3.1 \\
\hline
\end{tabular}

Sources: CBR, IEP calculations.

Increased inflow of corporate customers' assets in banks happened in September 2015 due to their foreign currency component. If ruble balances on accounts and deposits have increased over the month by $0.5 \%$ than the volume of assets in foreign currency went up by $11.6 \%$ for the same period. As a result, the share of corporate customers'assets denominated in foreign currency has reached its maximum from 2001.

The share of assets of organizations on time deposits continues prevail in the overall volume of corporate customers' assets. As of 1 September 2015, it constituted $59.6 \%$ in the course of 2015 and its level has not decreased below $58 \%$. If the volume of current and clearing accounts of corporate customers over a prolonged period continues equivalent to 15-20 turnover days of organizations, then the volume of time deposits as of 1 October 2015 ( $\mathrm{Rb} 11.83 \mathrm{bn}$ ) has not exceeded the level of monthly turnover of organizations.

In September 2015, banks continued reducing their debt before the Bank of Russia. During the month, its value fell by $\mathrm{Rb} 0.77$ trillion and for $\mathrm{Q} 3$ by more than one trillion rubles. Reduction concerned all major categories of the Bank of Russia instruments for supplying liquidity to commercial banks. For example, in September the volume of REPO transactions debt denominated in rubles fell by $\mathrm{Rb} 111.0 \mathrm{bn}$ and on other ruble loans - by Rb 376.0bn. In September, the value of banks debt before the Bank of Russia denominated in foreign currency has shrunk by $\$ 4.1 \mathrm{bn}$ to $\$ 26.8 \mathrm{bn}$.

Concurrently with the debt repayment before the Bank of Russia, banks attracted the Finance Ministry assets on their deposits. In September, total volume of assets on the Finance Ministry deposits has reached $\mathrm{Rb} 1.03$ trillion, thus growing over the month by more than Rb 350.0bn. Nevertheless, dynamics of the banks' aggregate debt before the money market regulators continues contracting practically over the whole period from the turn of the year when its volume amounted to $\mathrm{Rb} 9.87$ trillion or $12.7 \%$ of the aggregate liabilities of the banking sector. As of 1 October 2015, total liabilities of the banks before the Bank of Russia and Finance Ministry constituted Rb 6.79 trillion or $8.6 \%$ of the total liabilities of the banking sector. 


\section{Invested Assets}

Retail lending dynamic continues to be negative. However, over recent months, retail debt reduction before banks was at a minimum pace. In September, the volume of credit exposure has fallen by $0.2 \%$ and on the whole for Q3 - by $0.4 \%$. Annual increment of retail loans as of 1 October 2015 amounted to $-5.2 \%$.

The quality of the retail-lending portfolio continues deteriorating. The share of outstanding loans in the overall volume of retail debt as of 1 October 2015 has reached $8.3 \%$, thus growing over the month by 0.1 p.p. and from the turn of the year - by 2.2 p.p. Ratio of reserves for unexpected losses on loans granted to individuals to the volume of credit exposure as of the end of September exceeded $11.0 \%$. Both these indicators have exceeded maximum benchmarks of 20082010 crisis (7.7 and 10.9\%, respectively).

Meanwhile, situation with the volume of loans with late payments has somewhat improved. If in Q2, the share of loan payments missing their time according to the credit contracts constituted $18-20 \%$, than in September it fell to 16\%. However, it still is above 2013 levels (10-13\%) and of H! 2014 (12-14\%).

In September 2015, the corporate debt increased by $0.5 \%$ and on the whole for Q3 - by $2.1 \%$. In recent months, annual corporate loans growth rates remain at $8-9 \%$.

The corporate customers' debt on ruble loans went up for the fourth month in a row. Over the month, it went up by $0.9 \%$. In September, foreign currency loans, on the contrary, shrank by $0.6 \%$ in dollar terms.

In recent months, the quality of corporate segment of the credit portfolio has stabilized. In September, the share of loans past due in the total volume of corporate debt outstanding stayed on hold remaining at $5.5 \%$. In the meantime, reduction of the ruble debt outstanding is observed for the second month in a row.

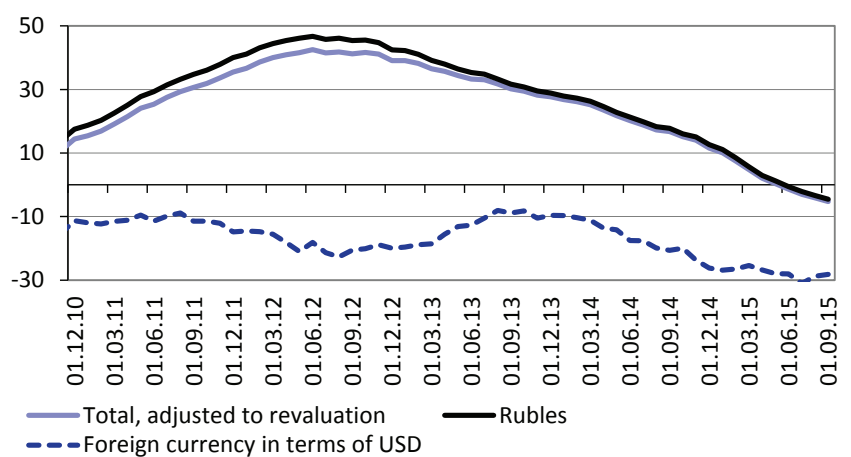

Sources: CBR, IEP calculations.

Fig. 6. The dynamics of the retail-lending portfolio to the corresponding date of the previous year (\%)

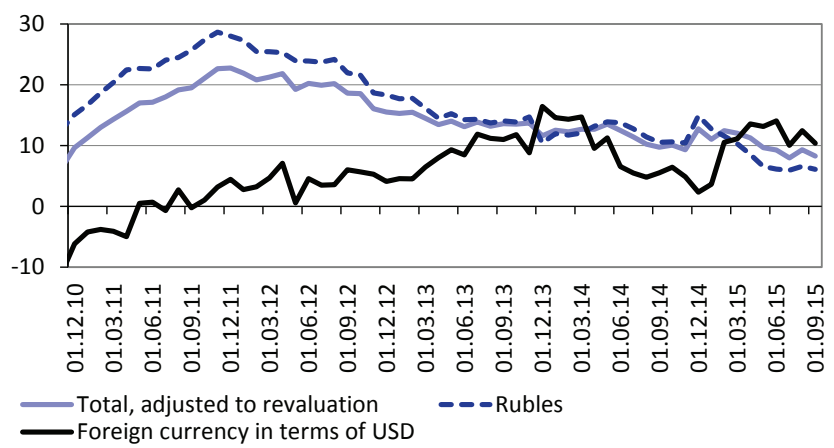

Sources: CBR, IEP calculations.

Fig. 7. The dynamics of the corporate lending portfolio to the corresponding date of the previous year (\%)

In September, it shrank from 7.2 to $7.0 \%$. The ratio of reserves to unexpected losses on loans granted to corporate customers to the total volume of corporate debt also fell from 8.2 to $8.0 \%$. Thus, main indicators of the corporate lending remain noticeably better than it was in 2009-2010 when the share of outstanding debt reached $6.6 \%$ and the ratio of reserves to loans $11.5 \%$.

COMPOSITION OF RUSSIA'S CREDIT ORGANIZATIONS' ASSETS (AS OF MONTH END), AS \% OF TOTAL

\begin{tabular}{|c|c|c|c|c|c|c|c|c|c|c|c|c|}
\hline & 12.09 & 12.10 & 12.11 & 12.12 & 12.13 & 06.14 & 12.14 & 03.15 & 06.15 & 07.15 & 08.15 & 09.15 \\
\hline Assets, Rb bn & 29430 & 33805 & 41628 & 49510 & 57423 & 61385 & 77663 & 74447 & 73513 & 74841 & 78413 & 79211 \\
\hline Cash and precious metals & 2.7 & 2.7 & 2.9 & 3.1 & 2.8 & 2.4 & 3.5 & 2.3 & 2.2 & 2.1 & 2.1 & 2.0 \\
\hline $\begin{array}{l}\text { Assets allocated in } \\
\text { Bank of Russia }\end{array}$ & 6.9 & 7.1 & 4.2 & 4.4 & 3.9 & 3.3 & 4.2 & 3.2 & 2.9 & 2.8 & 2.7 & 2.7 \\
\hline Interbank operations & 5.4 & 6.5 & 6.4 & 6.8 & 5.7 & 6.9 & 7.5 & 6.6 & 7.3 & 7.2 & 7.2 & 8.0 \\
\hline Foreign assets & 14.1 & 13.4 & 14.3 & 13.0 & 13.3 & 14.1 & 13.8 & 15.1 & 15.6 & 15.9 & 16.6 & 16.5 \\
\hline Population & 13.1 & 13.0 & 14.4 & 16.8 & 18.5 & 18.5 & 15.5 & 15.5 & 15.4 & 15.1 & 14.5 & 14.3 \\
\hline Corporate sector & 44.5 & 43.6 & 44.0 & 41.3 & 39.3 & 38.8 & 35.9 & 38.6 & 39.1 & 39.4 & 39.3 & 38.9 \\
\hline State & 4.2 & 5.1 & 5.0 & 3.2 & 3.1 & 3.4 & 3.1 & 3.9 & 4.0 & 4.3 & 4.6 & 4.5 \\
\hline Property & 2.7 & 2.6 & 2.3 & 2.2 & 2.0 & 1.9 & 1.6 & 1.6 & 1.7 & 1.6 & 1.6 & 1.5 \\
\hline
\end{tabular}

Sources: CBR, IEP calculations. 